\title{
Defining a new vision for the retinoblastoma gene: report from the 3rd International $\mathrm{Rb}$ Meeting
}

\author{
Seth M Rubin ${ }^{1^{*}}$ and Julien Sage $\mathrm{2}^{2^{*+}}$
}

\begin{abstract}
The retinoblastoma tumor suppressor (Rb) pathway is mutated in most, if not all human tumors. In the G0/G1 phase, Rb and its family members p107 and p130 inhibit the E2F family of transcription factors. In response to mitogenic signals, Cyclin-dependent kinases (CDKs) phosphorylate Rb family members, which results in the disruption of complexes between $\mathrm{Rb}$ and E2F family members and in the transcription of genes essential for $\mathrm{S}$ phase progression. Beyond this role in early cell cycle decisions, Rb family members regulate DNA replication and mitosis, chromatin structure, metabolism, cellular differentiation, and cell death. While the RB pathway has been extensively studied in the past three decades, new investigations continue to provide novel insights into basic mechanisms of cancer development and, beyond cancer, help better understand fundamental cellular processes, from plants to mammals. This meeting report summarizes research presented at the recently held 3rd International Rb Meeting.
\end{abstract}

Keywords: Retinoblastoma, Rb, p107, p130, E2F, CDK, Cyclin

\section{Background}

The $\mathrm{Rb}$ tumor suppressor was cloned more than 25 years ago from children with retinoblastoma [1-4]. This seminal discovery led to an intense research effort culminating in the elucidation of the $\mathrm{Rb}$ pathway and fundamental mechanisms governing the G1/S transition of the cell cycle. It is now understood that regulators and mediators of Rb function are deregulated in a large set of diverse pediatric and adult tumors. In the last 10 years, a number of experiments have shown that $\mathrm{Rb}$ controls many biological processes beyond cell cycle entry, including at other stages of the cell cycle, for cell survival and during cellular differentiation. At the molecular level, while E2F transcription factors are known to be critical mediators of Rb function, the $\mathrm{Rb}$ protein binds to more than 150 other proteins, such as tissue-specific transcription factors and chromatin remodeling enzymes (see [5-9] for recent reviews).

Major challenges in the field include determining the biochemical mechanisms carried out by multiple

\footnotetext{
*Correspondence: srubin@ucsc.edu; julsage@stanford.edu

${ }^{\dagger}$ Equal contributors

'Department of Chemistry and Biochemistry, University of California, Santa Cruz, CA 95064, USA

Full list of author information is available at the end of the article
}

Rb-containing complexes in cells, exploring the role of novel $\mathrm{Rb}$ functions in tumor suppression, and identifying the combinations of genetic alterations that result in tissue-specific cancers. The ultimate goal of the field is to discover novel therapeutic approaches to stop or slow the growth of human tumor cells with mutations in the $\mathrm{Rb}$ pathway. Accordingly, research on $\mathrm{Rb}$ and the networks around $\mathrm{Rb}$ in cells remains intense with publication of nearly 1,000 relevant journal articles a year.

Two previous international $\mathrm{Rb}$ conferences were organized in 2009 and 2011 in Toronto, Canada by Eldad Zacksenhaus and Rod Bremner. The success of these first two meetings coalesced a large group of investigators with a strong interest in participating in a scientific meeting focusing on the $\mathrm{Rb}$ pathway, which would be organized every other year in a rotating manner by active participants. 88 researchers in the $\mathrm{Rb}$ field recently gathered to exchange results and ideas at the 3rd International $\mathrm{Rb}$ Meeting, which was held October 7-10, 2013, in Monterey, CA, USA. The conference included 33 oral presentations and 45 posters. While we cannot summarize here all these studies, many of them unpublished, we highlight several topics discussed.

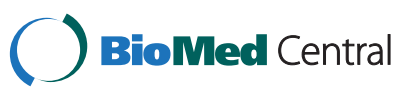

(c) 2013 Rubin and sage; licensee BioMed Central Ltd. This is an Open Access article distributed under the terms of the Creative Commons Attribution License (http://creativecommons.org/licenses/by/2.0), which permits unrestricted use, distribution, and reproduction in any medium, provided the original work is properly cited. The Creative Commons Public Domain Dedication waiver (http://creativecommons.org/publicdomain/zero/1.0/) applies to the data made available in this article, unless otherwise stated. 


\section{Meeting summary}

A number of presentations focused on the disease of retinoblastoma, the pediatric tumor after which the $\mathrm{Rb}$ gene was named. The recent publication of the first human retinoblastoma cancer genomes by Michael Dyer's group emphasized the very low number of alterations found in these tumors and suggested an epigenetic mechanism of tumorigenesis upon loss of Rb function [10-12]. Claudia Benavente from the Dyer lab presented new analyses of the genomes of pediatric tumors, including cancers with $R B$ mutations, and the St Jude's Children's Research Hospital now provides access to a large number of data and reagents (https://hospital.stjude.org/dbstp/). A number of other groups, including those of Josephine Dorsman and David MacPherson, are performing genomics studies on patient-derived retinoblastomas as well as tumors from genetically engineered mice [13-18]. While some of the human tumors clearly develop with few DNA alterations beyond $\mathrm{Rb}$ loss, these alterations may still provide key insights into the mechanisms of tumorigenesis upon loss of $\mathrm{Rb}$ function. Genomics and epigenomics studies of retinoblastoma and other Rb-deficient tumors are still in their infancy and, combined with cellular systems and mouse models, may identify novel therapeutic targets. In stimulating new work that could complement mouse models, David Cobrinik and his colleagues are exploring the mechanisms of cancer initiation in human fetal retinal cells upon Rb loss [19].

While $\mathrm{Rb}$ was identified nearly three decades ago, there are still no targeted therapies to treat Rb-deficient tumors. In an exciting development, several presenters discussed remarkable progress towards developing such therapeutics. Work from the laboratory of Erik Knudsen has underscored the differential response of $\mathrm{Rb}$ wildtype and $\mathrm{Rb}$-deficient breast cancer cells to chemotherapy, the latter often being more sensitive to classical chemotherapeutic agents $[20,21]$. Recent results from the laboratory of Rod Bremner demonstrate that reducing E2F or Cdk2 activity using small molecule inhibitors, even for a short period of time early during tumor development in mice, may be sufficient to prevent the growth of retinoblastoma [22]. These experiments and ongoing work suggest that such "prevention" strategies may help significantly reduce tumor burden in familial cases or when tumors are detected early. Beyond this targeted approach, other groups, including those of Eldad Zacksenhaus and Maria Alvarado-Kristensson, are performing high throughput screens to identify small molecules that may specifically block the expansion of $\mathrm{Rb}$ mutant cells, including $\mathrm{Rb}$-deficient triple negative breast cancer [23].

One of the most interesting aspects of the conference was the large number of presentations introducing novel functions for $\mathrm{Rb}$ pathway members. The groups of Peter
Sicinski, Philip Hinds, and Philipp Kaldis all identified novel functions for Cyclins and CDKs using state-ofthe-art mouse genetics approaches. These functions go beyond the classical cell cycle progression roles for these kinase complexes, and extend to the control of differentiation and organ/tissue function [24]. Similarly, the groups of Nicholas Dyson, Maxim Frolov, William Henry, David Johnson, Jacqueline Lees, and Chiaki Takahashi found new roles for $\mathrm{Rb}$ and E2F in various central cellular processes, including mitochondrial function, metabolism, the transcription of small RNAs, RNA translation, DNA repair, or cell migration $[7,25,26]$. Work from the laboratories of Timothy Hallstrom, Gustavo Leone, James Pipas (with Maria Teresa Saenz Robles), Julien Sage, and Ruth Slack underscored functional interactions between E2F transcription factors and other transcription factors such as beta-catenin, Sox2, Myc, YAP, or FoxO, uncovering complex regulatory networks controlling multiple cellular processes (e.g. [27-31]). The number of partners for $\mathrm{Rb}$ and E2F family members and the multitude of functions that they exert in cells bring the field to a new level of complexity.

A number of groups, including the laboratories of Ashby Morrison, Elizaveta Benevolenskaya, Jesus Paramio, and Fred Dick presented new evidence of a role for $\mathrm{Rb}$ in regulating chromatin structure using a combination of biochemical, molecular, and genetic studies [32,33]. Several groups (Seth Rubin, Joe Lipsick, James DeCaprio, Valerie Reinke, Susan Strome) have begun to explore the mechanisms of action of the DREAM (DP, Rb, E2F, and MuvB) and Myb-MuvB complexes in cells, including the identity and the structure of these complexes, how they control gene expression during the cell cycle and development, and how the complexes are regulated [34-36].

Another new area of investigation described at the conference was the analysis of cell cycle progression in single cells by Jan Skotheim, Lingchong You, and Tobias Meyer labs (postdoctoral fellow Sabrina Spencer) (e.g. [37-39]). When presented next to new results from the laboratory of Steven Dowdy (by Manuel Kaulich) on the kinetics of $\mathrm{Rb}$ phosphorylation by CDKs, these experiments help redefine the restriction point and when cells are committed to enter and conclude a cell cycle. Together these studies may soon modify the old textbook view of the G1/S checkpoint and the role of CDK activity in defining this checkpoint.

The $\mathrm{Rb}$ field has been primarily driven by the role of the $\mathrm{Rb}$ pathway in cell cycle control and cancer. However, interesting work in yeast (Jan Skotheim), in C. elegans (Susan Strome, Valerie Reinke), in D. melanogaster (Maxim Frolov, Nicholas Dyson, Joe Lipsick), and in plants (Wilhelm Gruissem and Arp Schnittger) was presented on the role of Rb-like and E2F-like molecules [35,40-47]. These studies further highlight a role of $\mathrm{Rb}$ in cell fate 
decisions that may have been conserved during evolution from fungi to mammals and plants [48].

\section{Conclusions}

The $\mathrm{Rb}$ field is vibrant and relevant to many areas of biology, including cancer biology, developmental biology, stem cell biology, and regenerative medicine. A major goal of the Rb meeting, and its highest impact, is to offer a unique forum for building a community of scientists working together, advancing scientific knowledge. The 3rd International $\mathrm{Rb}$ Meeting offered hope that 20 years of molecular studies would soon translate into novel therapeutic options in a large number of patients. At the same time, the conference further highlighted the need for many more years of biochemical, structural, cellular, and organismal studies to better understand the regulation and the mode of action of $\mathrm{Rb}$ in plants and animals. The 4th International $\mathrm{Rb}$ Meeting, which will take place in Boston in 2015 and will be organized by Drs. J. Lees (MIT), N. Dyson (MGH, Harvard Medical School), and J. DeCaprio (DFCI, Harvard Medical School), will with no doubt reveal further unexpected findings and continue to strengthen this field of intense research.

\section{Abbreviations}

Rb: retinoblastoma; CDK: Cyclin-dependent kinase.

\section{Competing interests}

The authors declare that they have no competing interests.

\section{Authors' contributions}

Both authors contributed equally to this manuscript and are listed in alphabetical order. Both authors read and approved the final manuscript.

\begin{abstract}
Acknowledgements
We would like to thank all the participants of the conference for contributing to its success and for sharing new and unpublished data, especially the steering committee, as well as all the speakers for helping us write this meeting summary. We are most grateful to the generous sponsors of the meeting: the Alex's Lemonade Stand Foundation (ALSF), the California Institute for Regenerative Medicine (CIRM), the California Tobacco-Related Disease Research Program (TRDRP), the Stanford Cancer Institute, and the Lucille Packard Children's Hospital at Stanford. Research on Rb in the Sage lab is supported by the Leukemia and Lymphoma Society, the ALSF, the NIH (R01 CA114102 and R21 CA167104). JS is the Harriet and Mary Zelencik Scientist in Children's Cancer and Blood Diseases. Research on Rb in the Rubin lab is supported by the NIH (R01 CA132685).
\end{abstract}

\section{Author details}

${ }^{1}$ Department of Chemistry and Biochemistry, University of California, Santa Cruz, CA 95064, USA. ²Departments of Pediatrics and Genetics, Stanford University, Stanford, CA 94305, USA.

Received: 19 November 2013 Accepted: 20 November 2013 Published: 21 November 2013

\section{References}

1. Friend SH, Bernards R, Rogelj S, Weinberg RA, Rapaport JM, Albert DM, Dryja TP: A human DNA segment with properties of the gene that predisposes to retinoblastoma and osteosarcoma. Nature 1986, 323:643-646.

2. Fung YK, Murphree AL, T'Ang A, Qian J, Hinrichs SH, Benedict WF: Structural evidence for the authenticity of the human retinoblastoma gene. Science 1987, 236:1657-1661.
3. Lee WH, Bookstein R, Hong F, Young $L$, Shew JY, Lee EY: Human retinoblastoma susceptibility gene: cloning, identification, and sequence. Science 1987, 235:1394-1399.

4. Dunn JM, Phillips RA, Becker AJ, Gallie BL: Identification of germline and somatic mutations affecting the retinoblastoma gene. Science 1988, 241:1797-1800.

5. Dick FA, Rubin SM: Molecular mechanisms underlying RB protein function. Nat Rev Mol Cell Biol 2013, 14:297-306.

6. Talluri S, Dick FA: Regulation of transcription and chromatin structure by pRB: here, there and everywhere. Cell Cycle 2012, 11:3189-3198.

7. Takahashi C, Sasaki N, Kitajima S: Twists in views on RB functions in cellular signaling, metabolism and stem cells. Cancer Sci 2012, 103:1182-1188.

8. Manning AL, Dyson NJ: RB: mitotic implications of a tumour suppressor. Nat Rev Cancer 2012, 12:220-226.

9. Chinnam M, Goodrich DW: RB1, Development, and Cancer. Curr Top Dev Biol 2011, 94:129-169.

10. Zhang J, Benavente CA, McEvoy J, Flores-Otero J, Ding L, Chen X, Ulyanov A, Wu G, Wilson M, Wang J, et al: A novel retinoblastoma therapy from genomic and epigenetic analyses. Nature 2012, 481:329-334.

11. Sage J, Cleary ML: Genomics: The path to retinoblastoma. Nature 2012, 481:269-270.

12. Benavente CA, McEvoy JD, Finkelstein D, Wei L, Kang G, Wang YD, Neale G, Ragsdale S, Valentine V, Bahrami A, et al: Cross-species genomic and epigenomic landscape of retinoblastoma. Oncotarget 2013, 4:844-859.

13. Rushlow DE, Mol BM, Kennett JY, Yee S, Pajovic S, Theriault BL, Prigoda-Lee NL, Spencer C, Dimaras H, Corson TW, et al: Characterisation of retinoblastomas without RB1 mutations: genomic, gene expression, and clinical studies. Lancet Oncol 2013, 14:327-334.

14. MacPherson D, Sage J, Kim T, Ho D, McLaughlin ME, Jacks T: Cell typespecific effects of $\mathrm{Rb}$ deletion in the murine retina. Genes Dev 2004, 18:1681-1694

15. MacPherson D, Conkrite K, Tam M, Mukai S, Mu D, Jacks T: Murine bilateral retinoblastoma exhibiting rapid-onset, metastatic progression and N-myc gene amplification. Embo J 2007, 26:784-794.

16. Chen D, Livne-Bar I, Vanderluit JL, Slack RS, Agochiya M, Bremner R: Cell-specific effects of RB or RB/p107 loss on retinal development implicate an intrinsically death-resistant cell-of-origin in retinoblastoma. Cancer Cell 2004, 5:539-551.

17. Zhang J, Schweers B, Dyer MA: The first knockout mouse model of retinoblastoma. Cell Cycle 2004, 3:952-959.

18. Mol BM, Massink MPG, van der Hout AH, Dommering CJ, Zaman JMA, Bosscha MI, Kors WA, Meijers-Heijboer HE, Kaspers GJL, Riele H, et al: High resolution SNP array profiling identifies variability in retinoblastoma genome stability. Genes Chromosom Cancer 2013, 53:1-14.

19. Xu XL, Fang Y, Lee TC, Forrest D, Gregory-Evans C, Almeida D, Liu A, Jhanwar SC, Abramson DH, Cobrinik D: Retinoblastoma has properties of a cone precursor tumor and depends upon cone-specific MDM2 signaling. Cell 2009, 137:1018-1031.

20. Witkiewicz AK, Ertel A, McFalls J, Valsecchi ME, Schwartz G, Knudsen ES RB-pathway disruption is associated with improved response to neoadjuvant chemotherapy in breast cancer. Clin Cancer Res 2012, 18:5110-5122.

21. Knudsen ES, Wang JY: Targeting the RB-pathway in cancer therapy. Clin Cancer Res 2010, 16:1094-1099.

22. Sangwan M, McCurdy SR, Livne-Bar I, Ahmad M, Wrana JL, Chen D, Bremner R: Established and new mouse models reveal E2f1 and Cdk2 dependency of retinoblastoma, and expose effective strategies to block tumor initiation. Oncogene 2012, 31:5019-5028.

23. Jiang Z, Deng T, Jones R, Li H, Herschkowitz JI, Liu JC, Weigman VJ, Tsao MS, Lane TF, Perou CM, Zacksenhaus E: Rb deletion in mouse mammary progenitors induces luminal-B or basal-like/EMT tumor subtypes depending on p53 status. J Clin Invest 2010, 120:3296-3309.

24. Lim S, Kaldis P: Loss of Cdk2 and Cdk4 induces a switch from proliferation to differentiation in neural stem cells. Stem Cells 2012, 30:1509-1520.

25. Hilgendorf Kl, Leshchiner ES, Nedelcu S, Maynard MA, Calo E, lanari A, Walensky LD, Lees JA: The retinoblastoma protein induces apoptosis directly at the mitochondria. Genes Dev 2013, 27:1003-1015.

26. Gjidoda A, Henry RW: RNA polymerase III repression by the retinoblastoma tumor suppressor protein. Biochim Biophys Acta 1829, 2013:385-392.

27. Leone G, Sears R, Huang E, Rempel R, Nuckolls F, Park CH, Giangrande P, Wu L, Saavedra HI, Field SJ, et al: Myc requires distinct E2F activities to induce S phase and apoptosis. Mol Cell 2001, 8:105-113. 
28. Tschop K, Conery AR, Litovchick L, Decaprio JA, Settleman J, Harlow E, Dyson N: A kinase shRNA screen links LATS2 and the pRB tumor suppressor. Genes Dev 2011, 25:814-830.

29. Nicolay BN, Bayarmagnai B, Moon NS, Benevolenskaya EV, Frolov MV: Combined inactivation of $\mathrm{pRB}$ and hippo pathways induces dedifferentiation in the Drosophila retina. PLoS Genet 2010, 6:e1000918.

30. Hallstrom TC, Mori S, Nevins JR: An E2F1-dependent gene expression program that determines the balance between proliferation and cell death. Cancer Cell 2008, 13:11-22.

31. Julian LM, Vandenbosch R, Pakenham CA, Andrusiak MG, Nguyen AP, McClellan KA, Svoboda DS, Lagace DC, Park DS, Leone G, et al: Opposing regulation of Sox 2 by cell-cycle effectors E2f3a and E2f3b in neural stem cells. Cell Stem Cell 2013, 12:440-452.

32. Andrusiak MG, Vandenbosch R, Dick FA, Park DS, Slack RS: LXCXEindependent chromatin remodeling by $\mathrm{Rb} / \mathrm{E} 2 \mathrm{f}$ mediates neuronal quiescence. Cell Cycle 2013, 12:1416-1423.

33. Beshiri ML, Holmes KB, Richter WF, Hess $S$, Islam AB, Yan Q, Plante L, Litovchick L, Gevry N, Lopez-Bigas N, et al: Coordinated repression of cell cycle genes by KDM5A and E2F4 during differentiation. Proc Natl Acad Sci USA 2012, 109:18499-18504.

34. Petrella LN, Wang W, Spike CA, Rechtsteiner A, Reinke V, Strome S: synMuv $B$ proteins antagonize germline fate in the intestine and ensure $C$. elegans survival. Development 2011, 138:1069-1079.

35. DeBruhl H, Wen H, Lipsick JS: The complex containing Drosophila Myb and RB/E2F2 regulates cytokinesis in a histone $\mathrm{H} 2 \mathrm{Av}$-dependent manner. Mol Cell Biol 2013, 33:1809-1818.

36. Sadasivam S, Decaprio JA: The DREAM complex: master coordinator of cell cycle-dependent gene expression. Nat Rev Cancer 2013, 13:585-595.

37. Spencer SL, Cappell SD, Tsai FC, Overton KW, Wang CL, Meyer T: The Proliferation-Quiescence decision is controlled by a Bifurcation in CDK2 activity at mitotic exit. Cell 2013, 155:369-383.

38. Doncic A, Skotheim JM: Feedforward regulation ensures stability and rapid reversibility of a cellular state. Mol Cell 2013, 50:856-868.

39. Wong JV, Li B, You L: Tension and robustness in multitasking cellular networks. PLoS Comput Biol 2012, 8:e1002491.

40. Wang D, Kennedy S, Conte D Jr, Kim JK, Gabel HW, Kamath RS, Mello CC, Ruvkun G: Somatic misexpression of germline P granules and enhanced RNA interference in retinoblastoma pathway mutants. Nature 2005, 436:593-597.

41. Kudron M, Niu W, Lu Z, Wang G, Gerstein M, Snyder M, Reinke V: Tissue-specific direct targets of Caenorhabditis elegans Rb/E2F dictate distinct somatic and germline programs. Genome Biol 2013, 14:R5.

42. Gutzat R, Borghi L, Gruissem W: Emerging roles of RETINOBLASTOMARELATED proteins in evolution and plant development. Trends Plant Sci 2012, 17:139-148.

43. Nicolay BN, Gameiro PA, Tschop K, Korenjak M, Heilmann AM, Asara JM, Stephanopoulos G, lliopoulos O, Dyson NJ: Loss of RBF1 changes glutamine catabolism. Genes Dev 2013, 27:182-196.

44. Bayarmagnai B, Nicolay BN, Islam AB, Lopez-Bigas N, Frolov MV: Drosophila GAGA factor is required for full activation of the $\mathrm{dE2f1-Yki/Sd} \mathrm{transcriptional}$ program. Cell Cycle 2012, 11:4191-4202.

45. Weimer AK, Nowack MK, Bouyer D, Zhao X, Harashima H, Naseer S, De Winter F, Dissmeyer N, Geldner N, Schnittger A: Retinoblastoma related1 regulates asymmetric cell divisions in Arabidopsis. Plant Cell 2012, 24:4083-4095.

46. Zhao X, Harashima H, Dissmeyer N, Pusch S, Weimer AK, Bramsiepe J, Bouyer D, Rademacher S, Nowack MK, Novak B, et al: A general G1/S-phase cell-cycle control module in the flowering plant Arabidopsis thaliana. PLoS Genet 2012, 8:e1002847.

47. Nowack MK, Harashima H, Dissmeyer N, Zhao X, Bouyer D, Weimer AK, De Winter F, Yang F, Schnittger A: Genetic framework of cyclin-dependent kinase function in Arabidopsis. Dev Cell 2012, 22:1030-1040.

48. Calo E, Quintero-Estades JA, Danielian PS, Nedelcu S, Berman SD, Lees JA: $\mathrm{Rb}$ regulates fate choice and lineage commitment in vivo. Nature 2010, 466:1110-1114.

doi:10.1186/1747-1028-8-13

Cite this article as: Rubin and Sage: Defining a new vision for the retinoblastoma gene: report from the 3rd International Rb Meeting. Cell Division 2013 8:13.

\section{Submit your next manuscript to BioMed Central and take full advantage of:}

- Convenient online submission

- Thorough peer review

- No space constraints or color figure charges

- Immediate publication on acceptance

- Inclusion in PubMed, CAS, Scopus and Google Scholar

- Research which is freely available for redistribution 